\title{
System zarządzania projektami w przedsiębiorstwie wielozakładowym
}

https://doi.org/10.33141/po.2005.09.05

Przegląd Organizacji, Nr 9 (788), 2005, ss. 24-27

www.przegladorganizacji.pl

Towarzystwo Naukowe Organizacji i Kierownictwa (TNOiK)

Andrzej Karbownik, Seweryn Tchórzewski

\section{Wprowadzenie}

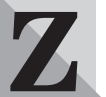
arządzanie projektami w przedsiębiorstwie jest praktycznym sposobem na wprowadzanie zmian $\mathrm{w}$ realizowanych procesach wytwórczych lub usługowych. W przedsiębiorstwie zorientowanym na procesy projekty są realizowane obok jego podstawowej działalności operacyjnej. W takim przedsiębiorstwie projekt wywołuje zazwyczaj konflikt $\mathrm{z}$ jego normalnym funkcjonowaniem. Wynika to z oporu wobec zmian, jakie projekt wprowadza. Pojawia się zatem zaburzające oddziaływanie projektu na pracę przedsiębiorstwa i im bardziej jest ono zorientowane na procesy, tym większy jest konflikt związany z realizacją procesu zarządzania projektem.

W przedsiębiorstwie zorientowanym na procesy należy tworzyć w systemie zarządzania przedsiębiorstwem korzystne warunki do zarządzania projektami. Zbiór korzystnych warunków do realizacji projektów można określić jako system zarządzania projektami. W artykule zostanie zaprezentowana pewna koncepcja takiego systemu bazująca na rozwiązaniach praktycznych, która przez autorów artykułu została zastosowana w kilku dużych przedsiębiorstwach jedno - i wielozakładowych.

\section{Model procesu zarządzania projektami}

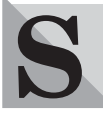

ystem zarządzania projektami w przedsiębiorstwie w ujęciu procesowym opiera się na czteroetapowym modelu zobrazowanym na rys. 1 .

W modelu tym wyróżnia się następujące etapy.

\section{- Etap 1 - Ustanowienie projektu}

Etap ten ma na celu określenie wymogów projektu, powołanie kierownika projektu, ustanowienie zespołu projektowego i przygotowanie go do pracy.

\section{- Etap 2 - Planowanie projektu}

Etap ten obejmuje następujące działania: określenie zadań do realizacji w projekcie, czyli struktury podziału pracy, opracowanie harmonogramu realizacji zadań i terminu osiągania celu projektu, określenie punktów kontrolnych w harmonogramie, czyli kamieni milowych, przydzielenie zasobów do zadań, czyli alokacja zasobów, opracowanie budżetu projektu i analiza ryzyka projektu.

\section{- Etap 3 - Realizacja i monitorowanie pro- jektu}

Etap ten polega na wykonywaniu zadań, które zostały ustalone na etapie planowania projektu. Następuje kontrola realizacji projektu z uwagi na zgodność z planem harmonogramu, budżetem i planem wykorzystania zasobów.

\section{- Etap 4 - Zamknięcie projektu}

Etap ten ma na celu zakończenie prac związanych z realizacją projektu i ich rozliczenie. Sporządza się zazwyczaj raport końcowy z realizacji projektu.

\section{System zarządzania projektami w przedsiębiorstwie}

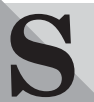

ystem zarządzania projektami w przedsiębiorstwie tworza: - dyrektor projektów, • biuro projektów, $\bullet$ kierownik projektów (kierownicy projektów), zespół projektowy (zespoły projektowe).

Wzajemne relacje pomiędzy powyższymi elementami systemu zarządzania projektami (SZP) w przedsiębiorstwie zostały zobrazowane na rys. 2 i krótko scharakteryzowane poniżej.

Dyrektor projektów pełni funkcję głównego koordynatora projektów realizowanych w przedsiębiorstwie. Powinna to być osoba z kierownictwa przedsiębiorstwa. Jego rolą jest ustanawianie projektów, wyznaczanie kierowników projektów, akceptacja składów zespołów projektowych, wspieranie kierowników projektów w dostępie do zasobów przedsiębiorstwa, ustanawianie formy monitorowania i kontroli realizacji projektów, okresowe przedstawianie kierownictwu przedsiębiorstwa informacji odnośnie do realizowanych projektów.

Biuro projektów pełni funkcję wspomagająca dla dyrektora projektów i równocześnie dla kierowników projektów. Wspiera dyrektora projektów - biuro projektów gromadzi informacje o przygotowywanych i realizowanych projektach $\mathrm{w}$ formie zorganizowanego monitoringu projektów oraz prowadzi archiwum o projektach zrealizowanych. Do wspierania działalności kierowników projektów biuro projektów dostarcza wiedzy w zakresie zarzadzania projektami oraz opracowuje i wdraża standardy postępowania w procesie zarządzania projektami w przedsiębiorstwie. 


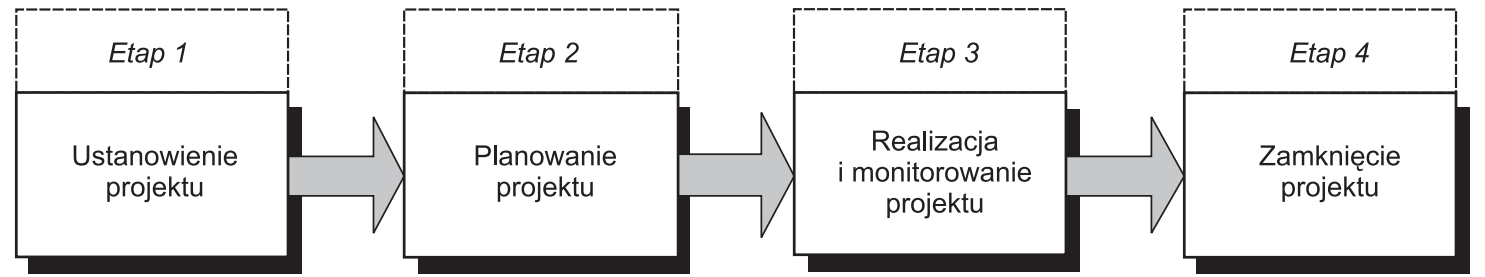

Rys. 1. Model procesu zarządzania projektami

Źródło: opracowanie własne publikowane w pracy [2].

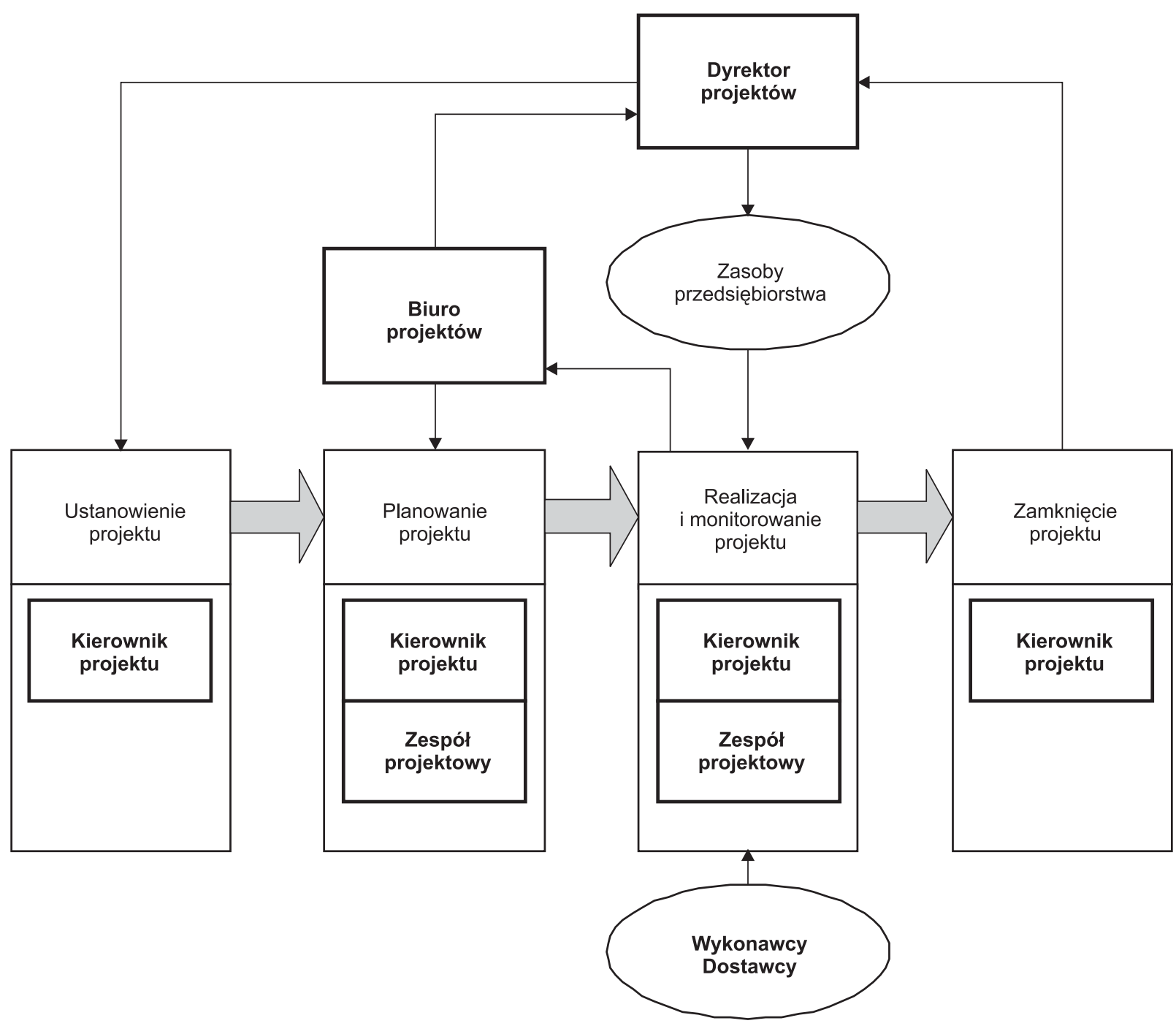

Rys. 2. System zarządzania projektami w przedsiębiorstwie

Źródło: opracowanie własne publikowane w pracy [3].

Kierownik projektu jest w pełni odpowiedzialny za przygotowanie i realizację projektu. Jego zadaniem jest utworzenie zespołu projektowego i kierowanie nim, tzn. organizowanie i koordynacja pracy poszczególnych jego członków. Na etapie realizacji projektu jego zadaniem jest kontrola realizacji projektu.
Zespół projektowy jest powoływany przez kierownika projektu w celu wykonania prac w ramach przygotowania projektu, a następnie jego realizacji. Każdy z członków zespołu projektowego powinien posiadać wysokie umiejętności merytoryczne w przedmiocie projektu oraz zdolność do współpracy z innymi członkami zespołu. 


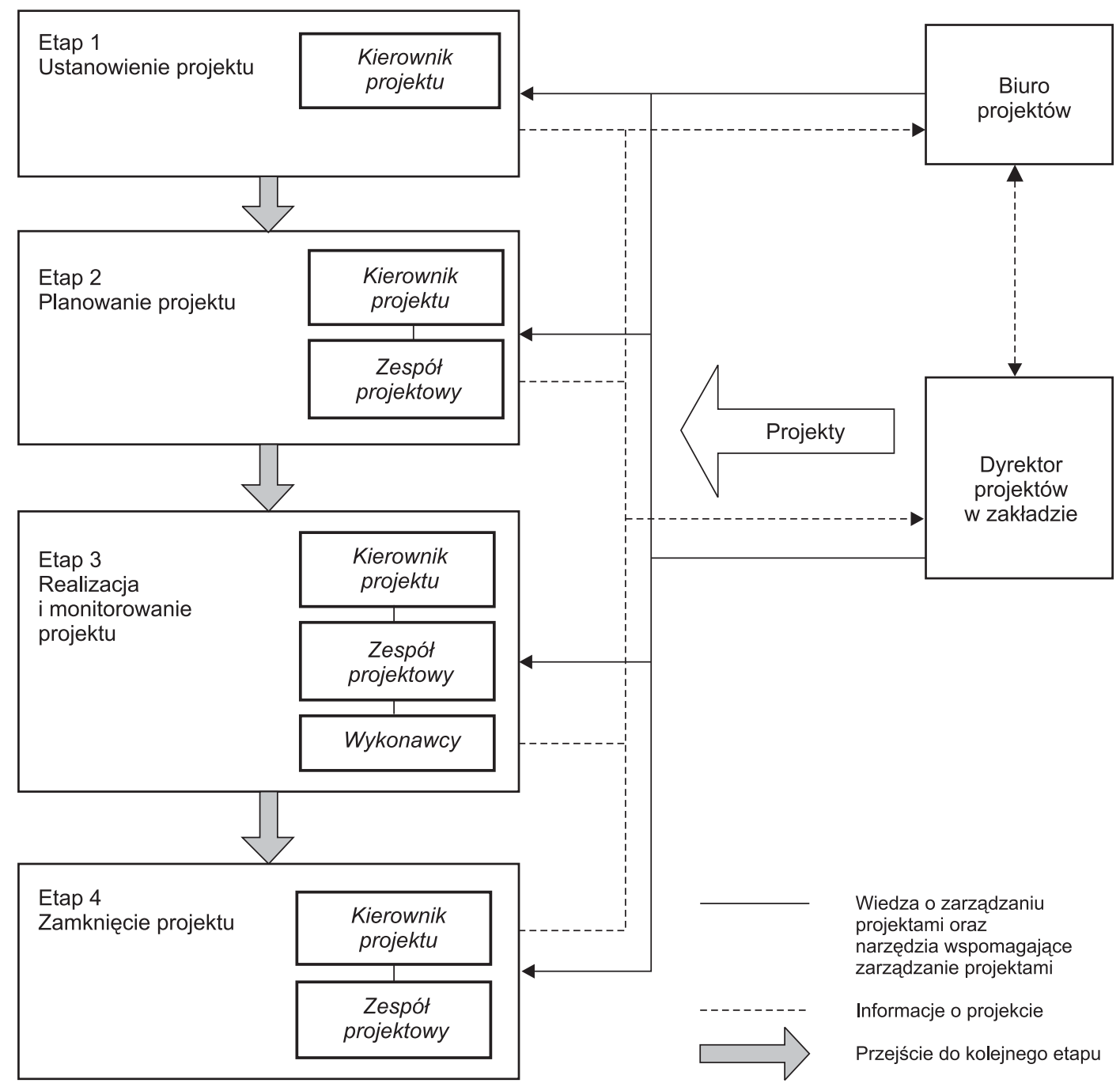

Rys. 3. System zarządzania projektami w przedsiębiorstwie wielozakładowym na szczeblu zakładu Źródło: opracowanie własne.

Przedstawiony schematycznie na rys. 2 system zarzadzania projektami w przedsiębiorstwie jest możliwy do zastosowania w przedsiębiorstwie, w którym nie wydziela się zakładów w jego strukturze organizacyjnej. Możliwy jest zatem do zastosowania w ramach struktury funkcjonalnej przedsiębiorstwa.

Jeżeli przedsiębiorstwo posiada strukturę organizacyjną wielozakładową, czyli dywizjonalną, w systemie zarządzania projektami powinny występować elementy w odniesieniu do poszczególnych zakładów i w odniesieniu do całego przedsiębiorstwa. W takim przypadku należy ustanowić dyrektora projektów w zakładzie (rys. 3) oraz dyrektora projektów w przedsiębiorstwie (rys. 4).

Biuro projektów powoływane tylko na szczeblu przedsiębiorstwa powinno ustanowić system monitorowania projektów odrębnie dla projektów realizowanych w zakładzie i odrębnie dla projektów realizowanych na szczeblu przedsiębiorstwa.

Funkcjonowanie systemu zarządzania projektami w przedsiębiorstwie nie byłoby możliwe bez ustanowienia odpowiednich procedur dla każdego z etapów procesu zarządzania projektami, które zostały przedstawione na rys. 1.

W systemie zarządzania projektami wyróżniamy cztery procedury główne odpowiadające kolejnym etapom modelu procesu zarządzania projektem, którymi są procedury:

- ustanowienia projektu P1,

- planowania projektu P2,

- realizacji i monitorowania projektu P3,

- zamknięcia projektu P4.

Zestaw procedur głównych uzupełniony jest o zestaw procedur szczegółowych, którymi sa procedury:

- utworzenia zespołu projektowego P1.1,

- opracowania harmonogramu projektu P2.1,

- wykorzystania zasobów w projekcie P2.2,

- opracowania budżetu projektu P2.3,

- wykorzystania narzędzia informatycznego w zarządzaniu projektem P2.4,

- wyłaniania wykonawców zadań w projekcie P2.5,

- kontroli realizacji projektu 3.1.

Każda z wymienionych procedur opisuje sposób postępowania osób i jednostek bioracych udział w pro- 


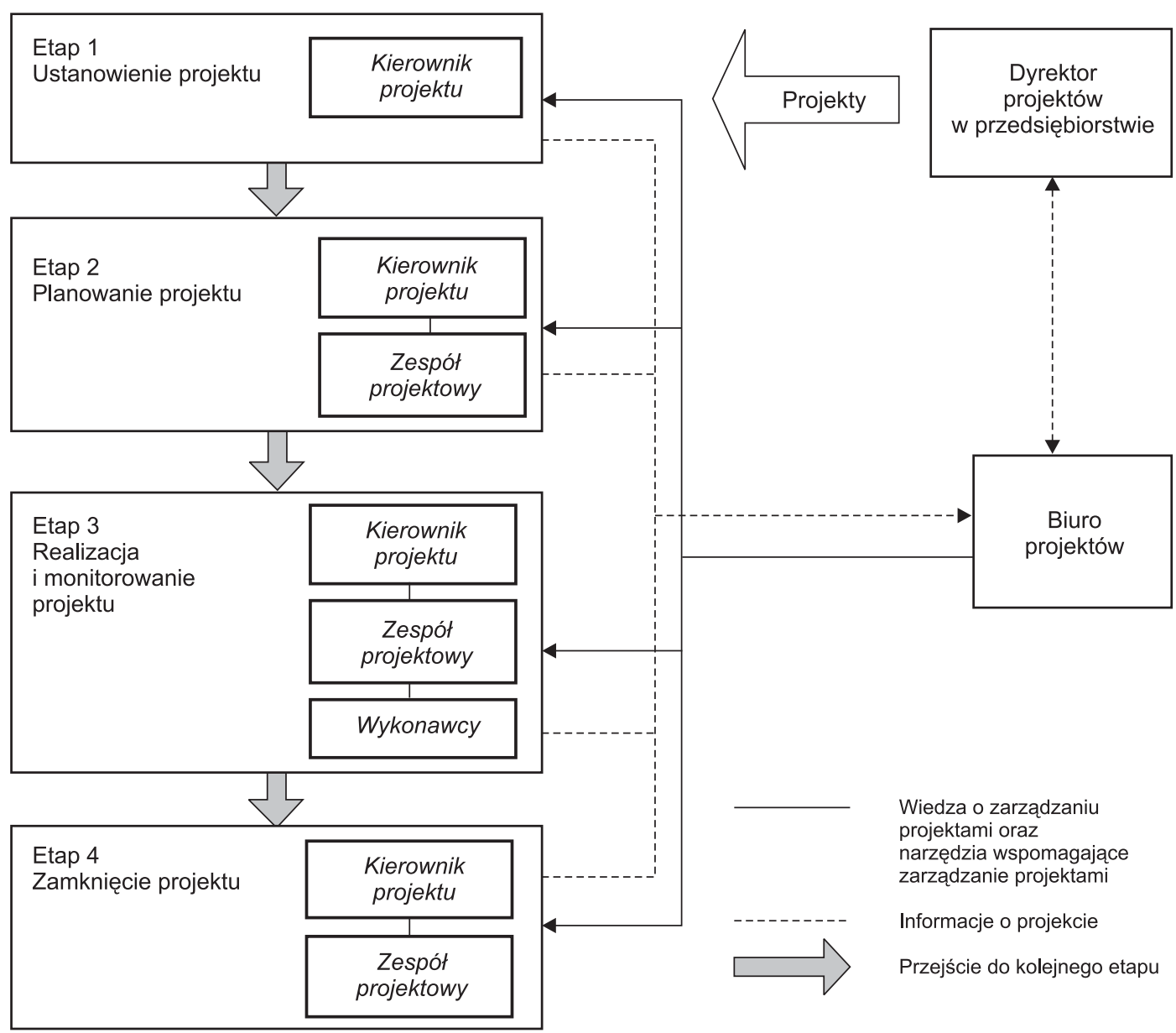

Rys. 4. System zarządzania projektami w przedsiębiorstwie wielozakładowym na szczeblu przedsiębiorstwa

Źródło: opracowanie własne.

jekcie oraz realizowane przez nich funkcje. Zostały one szczegółowo zaprezentowane w pracy [4].

\section{Podsumowanie}

- W przedsiębiorstwie zorientowanym na procesy należy tworzyć w systemie zarządzania przedsiębiorstwem korzystne warunki do zarządzania projektami. Takie korzystne warunki można ujać w postaci systemu zarządzania projektami w przedsiębiorstwie. - System zarządzania projektami w przedsiębiorstwie wielozakładowym tworzą: dyrektor projektów w przedsiębiorstwie, dyrektorzy projektów w zakładach, kierownicy projektów, zespoły projektowe.

- Istotnym wsparciem dla projektów realizowanych $\mathrm{w}$ przedsiębiorstwie powinna być niewielka jednostka organizacyjna pod nazwą „Biuro projektów”. Może ona spełniać funkcję doradczą, wykonawczą i kontrolną, przy czym w przedsiębiorstwie wielozakładowym należy zwrócić szczególną uwagę na jego funkcję doradczą w zakresie projektów realizowanych w poszczególnych zakładach.

- Funkcjonowanie systemu zarządzania projektami w przedsiębiorstwie wielozakładowym umożliwia stosowanie wielu procedur, które opisują sposób postępowania osób i jednostek organizacyjnych przedsię- biorstwa bioracych udział w projekcie oraz realizowane przez nie funkcje. prof. $z w . d r$ hab. inz. Andrzej Karbownik dr inż. Seweryn Tchórzewski Politechnika Śląska w Gliwicach Wydział Organizacji i Zarządzania w Zabrzu Katedra Zarzadzania Przedsiębiorstwem i Organizacji Produkcji

\section{BIBLIOGRAFIA}

[1] FRAME D.J., Zarzadzanie projektami w organizacjach, WIG-Press, Warszawa 2001.

[2] KARBOWNIK A., TCHÓRZEWSKI S., System zarzadzania projektami $w$ przedsiębiorstwie, [w:] Nowoczesność przemystu i ustug - nowe wyzwania, tom I, pod redakcją J. PYKI, Wyd. TNOiK, Katowice 2004.

[3] KARBOWNIK A., Rola i miejsce zarzadzania projektami $w$ przedsiebiorstwie, [w:] Zarzadzanie przedsiebiorstwem - ekonomia, prawo, kultura, etyka, pod redakcją W. SITKO, Lubelskie Centrum Marketingu, Lublin 2004.

[4] KARBOWNIK A., TCHÓRZEWSKI S., Procedury w systemie zarzadzania projektami w przedsiębiorstwie, VIII Konferencja Project Management, Warszawa 2004.

[5] PAWLAK M., Struktury organizacyjne zarzadzania projektami, „Przeglad Organizacji”, nr 1/2004,.

[6] SZPERKOWSKA M., ŚWIĘTANOWSKI A., Globalne $z a-$ rzadzanie projektami $w$ przedsiębiorstwie, czyli biuro projektów, V Konferencja Project Management, Szczyrk 2001. 